\title{
THE LIMITATIONS OF THE EXCULPATORY CRITIQUE: A RESPONSE TO MIKKEL BOLT RASMUSSEN
}

\section{Grant Kester}

\begin{abstract}
This essay constitutes a response to Mikkel Bolt Rasmussen's essay "A Note on Socially Engaged Art Criticism". In particular, the essay focuses on the concept of an "exculpatory critique". This term refers to a set of arguments in contemporary art criticism which contend that artistic practices that engage directly with processes of social or political change sacrifice their aesthetic validity while also providing an ideological justification for existing systems of domination. Kester seeks to demonstrate some of the shortcomings involved in this critique by examining the underlying model of political transformation on which it is based and outlining an alternative account of art's role in social action.
\end{abstract}

\section{KEYWORDS}

Socially engaged art, Socially engaged art criticism, Grant Kester, Mikkel Bolt Rasmussen, FIELD: A Journal of Socially Engaged Art Criticism, Exculpatory Critique, Th.W. Adorno, Lava la Bandera

This practico-material inertia of the real presupposes the exceptional moment, the Blitz of reason, the Jetzt of the moment of rupture. I see this as an internalization of Leninism ... Along with this comes an aristocratic attitude and a definition of the intellectual as one who is capable of voluntaristically pointing the way, as a Nietzschean intellectual capable of breaking through by force of will.

Alice Jardine and Brian Massumi, "Interview with Toni Negri," $(1988)^{1}$

\section{PRELIMINARY CLARIFICATIONS}

I want to thank Mikkel Bolt Rasmussen for his thoughtful remarks on socially engaged art criticism, my own research, and FIELD. I especially appreciate his willingness to share his observations with me in advance, and to allow me the opportunity to respond. $\mathrm{He}$ also generously provided me with some of his other recent essays, which I will respond to in part below. This exchange has allowed 
me to return to issues I have addressed in the past and elaborate on them with a deeper, and hopefully more nuanced, understanding. It also touches directly on questions that are central to my current research. Since many of the points that Rasmussen raises in his essay reiterate criticisms that have been made by other writers during the past few years I will use his essay as a jumping off point for some broader remarks on the analysis of socially engaged art (SEA). To that extent I will take his comments as representing a problématique, as Althusser would say. That is, I see them as framing a particular constellation of issues in a way that reveals some of the constraints of existing paradigms in contemporary art theory more generally. In this manner I hope to justify, or at least excuse, the lengthiness of my response. Before turning to the more substantive questions that Rasmussen raises I will briefly address some issues that may be based on simple misunderstandings or in response to which the reader can be referred to other works. In his essay Rasmussen make the following claims:

One of the problems with Kester's new socially engaged art criticism, which mimics to a large extent the practice of socially engaged art, is its reliance on an adjusted Habermasian notion of communication in which dialogue leads to empathy and recognition (of the other). The critic should not focus primarily on the formal aspects of an artwork but, instead, report with empathy and evaluate socially engaged art's ability to listen to the context and the audience. It is about establishing an "empathetic identification" between artists and their collaborators. There is a problematic privileging of consensus and inter-subjectivity here that tends to recoil from more radical or 'unreasonable' demands that are less interested in establishing a dialogue or empathy than in making visible processes of exclusion and lines of fracture that do not disappear because the artist (and the critic) have good intentions and wish to mobilize a local community.

There are two, related, points to respond to here. ${ }^{2}$ Rasmussen's contention that I privilege consensus over criticality or dissensus, is one that I have responded to on several occasions over the last few years. Rather than review all of these responses in detail I would simply direct the reader to my discussions of the issue of consensus (and the discourse of "reform" and "revolution") in chapters one and three of The One and the Many, as well as in "The Sound of Breaking Glass" (E-flux journal, \#30, December 2011 and \#31, January 2012), “The Device Laid Bare: On Some 
Limitations in Current Art Criticism” (E-flux journal \#50, 2013) and "On the Relationship Between Theory and Practice in Socially Engaged Art” (A Blade of Grass website, July 2015). At the methodological level the problem stems from the tendency of critics to project a synchronic model of analysis (in which a given work is conceived of as either consensual or dissensual) on to projects that are diachronic in nature, and which often involve a series of movements through phases of both conciliation and contention or disagreement. The interactions between Tania Bruguera, Cuban authorities and a broader public that unfolded following the cancellation of her 2014 Tatlin's Whisper 6 performance in Havana's Plaza de la Revolución (\#YoTambiénExijo) are exemplary in this regard. I would also note here that my interest in artistic practices that incorporate provisional forms of consensus in my first book, Conversation Pieces, emerged in response to a tendency in contemporary art theory to valorize an often crudely defined concept of dissensus and negation. This is a critique that I first developed in my “Rhetorical Questions” essay (Afterimage, January 1993).

A related difficulty, from my perspective, is that this approach ignores the key differential in some SEA projects between the modes of inter-subjective exchange that occur among a given set of collaborators in developing a gesture or work, and the relationship of that work to a specific site of practical resistance. A concrete example might make this point clearer. The Lava la Bandera project, produced in Peru during the late 1990s and early 2000s, began when a small group of artists and activists staged a ritual washing of the Peruvian flag in the Plaza Mayor in central Lima. They intended this as a protest against the corruption of the Fujimori regime. The gesture, unexpectedly, spread quite rapidly, and was soon being repeated in plazas throughout the country (not without risk, since the police would often attempt to prevent this performance from taking place). The "viral" proliferation of this gesture catalyzed a sense of solidarity, resistance, and shared agency in the Peruvian public that contributed to Fujimori's downfall and removal from office. The solidarity, and empathy, that unfolded among the participants in the washing action was integral to the realization of a very "unreasonable" (or at least unrealistic) demand. Moreover, the simple gesture of washing the flag was recognized, quite correctly, by the Fujimori regime as a direct assault on its legitimacy (hence their deployment of the police and military to block it). ${ }^{3}$

The second problem with Rasmussen's formulation is the assumption that one can simply "make visible processes of exclusion," thereby catalyzing a "radical" demand of some kind. This 


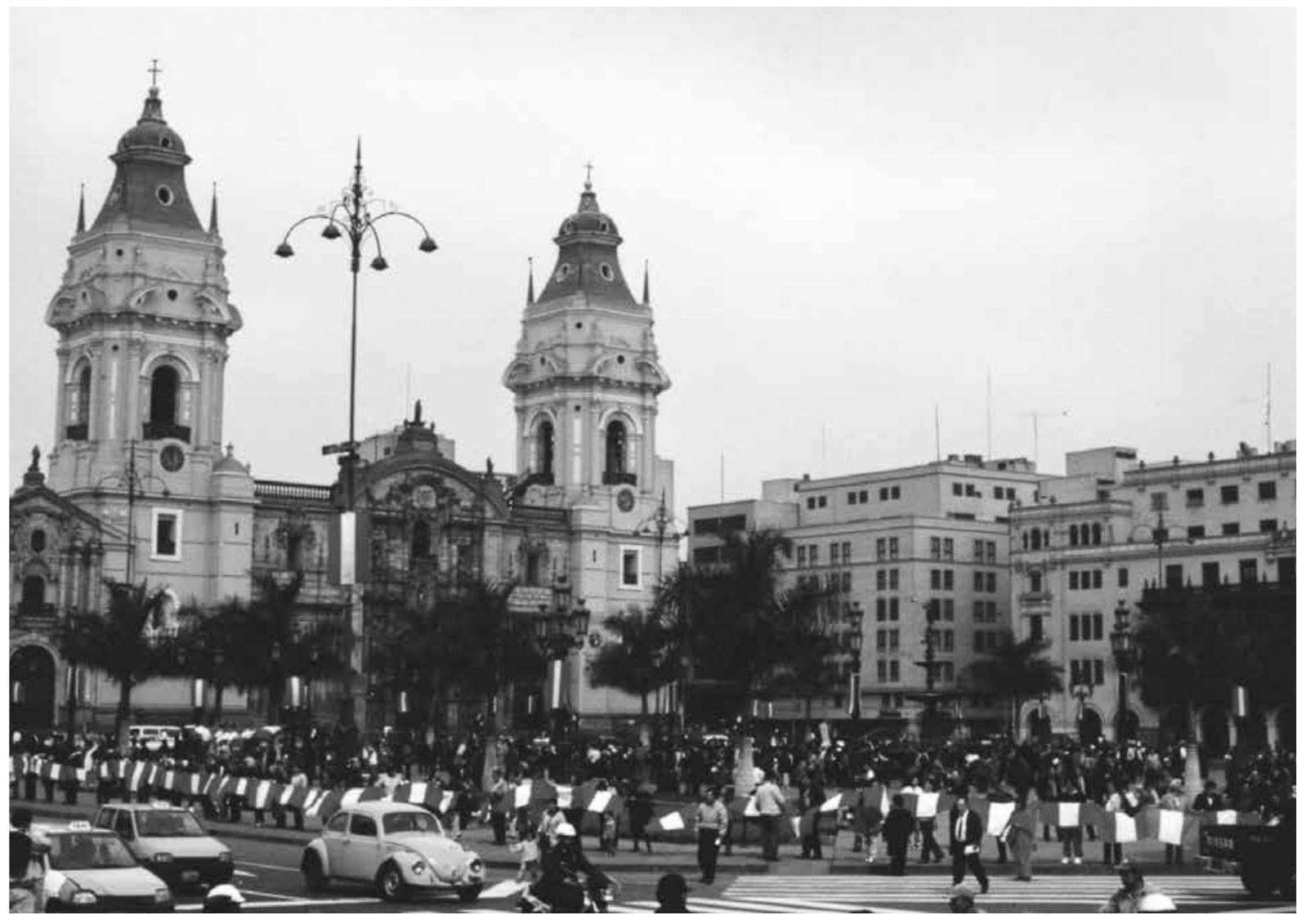

Colectivo Sociedad Civil, Lava la Bandera,

Plaza Mayor, Quito, Ecuador (2000) 
optical paradigm assumes the self-evidence of class repression (if only people knew of - or could be made aware of - their repression, or that of others, they would be compelled to act). But of course we know about all kinds of suffering, oppression, and exclusion and often do nothing. We have a century or more of art, as well as social documentary photography and film, that has dedicated itself to revealing ostensibly repressed or forbidden truths about the nature of social and political oppression (the same could be said about theoretical texts that "expose" the violence of neo-liberal capitalism). Moreover, this act of pseudo-revelation (the viewer often knows the truth to be revealed in advance) is a standard feature of contemporary art, evident most clearly in Santiago Sierra's installations which ostensibly force the reluctant art world viewer to acknowledge their own complicity in the system of global domination through the performative reiteration of its violence (while selling artifacts of that re-enactment for tens of thousands of dollars to the system's primary beneficiaries). This, of course, is the necessary corollary to a reductive opposition between projects that are purely disruptive and those that are naively consensual. The modalities of disruption we typically encounter in the arts have long ago succumbed to a kind of repressive re-sublimation in which the ostensibly audacious attack on the viewer's consciousness becomes simply another occasion for aesthetic delectation and profit maximization. What we require is a far more nuanced account of both consensus and dissensus as experiential modes in contemporary art and political resistance. I am hopeful that we can agree that the psychic and emotional economy behind the gesture of unveiling or revealing suffering and exclusion is complex, and often contradictory. I agree with Rasmussen that there is a persistent need to expose the various forms of repression that characterize the neo-liberal order today, but I believe it is a mistake to detach this gesture from the modes of solidarity formation, critique and resistant practice that are necessary to catalyze change (one thinks here of the Escraches of H.I.J.O.S and Grupo Etc. in Argentina during the late 1990s). ${ }^{4}$ I will address two other minor questions in the form of an endnote here. ${ }^{5}$

\section{THE EXCULPATORY CRITIQUE}

The second, and more productive, set of questions that Rasmussen raises address issues of autonomy, activism and social change. Rasmussen's primary critique, as I understand it, is that SEA (at least as it is presented in my own research) is politically naïve and even threatens to block or retard the emergence of a more authentically 
revolutionary form of cultural activism. Before pursuing this analysis further I want to make an initial conceptual clarification, related to Rasmussen's concept of SEA as based on little more than "modest proposals ... in which art has become a kind of socially reparatory activity that addresses very specific problems and tries to highlight or solve them." ${ }^{6}$ It would appear that the "modesty" that concerns Rasmussen is related to the scalar or spatial nature of a given practice ("addressing very specific" or local problems). But surely all forms of resistance begin at the local level, even as they also require a global awareness. I suspect what Rasmussen desires is a project that "immodestly" proclaims its revolutionary intention and overtly criticizes capitalism. Here the absence of an existing revolutionary movement (which could operate at the global rather than the local or regional scale) is compensated for at the discursive level by various rhetorical gestures (art projects that call for the downfall of capitalism or "make radical demands," etc.). I would argue, however, that these rhetorical gestures can themselves be viewed as "modest" at the level of social or political generativity (and are easily enough co-opted or ignored).

The challenge that Rasmussen confronts in this criticism arises from the degree of imprecision he introduces between rhetorical effect (the concept of art as primarily the expressive enunciation of an a priori political position or demand that operates at the level of semblance) and art that is developed through the reciprocal testing of political norms and boundaries through situational action. Thus, a gesture can easily enough be locally-scaled (and therefore "modest" or limited at the spatial level) but also tied to incipient or openly manifest forms of political opposition that are anti-capitalist in orientation. At the same time, there are any number of "modest" gestures in recent "social art practice" that are locally-scaled while also trafficking in de-politicized forms of conviviality that are highly problematic. Rasmussen's critique gives us no way to distinguish between these two modalities of practice. The problem with the second variant, of course, is the assumption that one can "solve" problems that are clearly structural or systematic in nature, rather than viewing engagement with them as the starting point for broader forms of resistance. It is also necessary here to understand the tactical distinction between the modes of pragmatic and rhetorical action that emerge in projects produced in conjunction with organized social movements or collectivities (what I term "politically coherent communities" in Conversation Pieces) and those that rely on more conventional forms of aesthetic autonomy (the work of Sierra, Thomas Hirschhorn, etc.). 
Rasmussen frames his analysis in terms of art's "dual” function. By art's "dual nature" I believe he is referring to the complex set of ideas that circulate around the perceived autonomy of art and aesthetic experience in the modern period. In this context art functions as both a prefigurative anticipation of a new, non-coercive form of society (Kant's sensus communis, Hegel's aesthetic state and, in the Marxist tradition, the period of perfect social harmony that will follow the Dictatorship of the Proletariat). Rasmussen's explication of this history takes the following form.

From German Romanticism through Critical Theory and onwards toward the Situationists, we have different attempts to describe this ambiguity. Two of them will have to suffice here: In the 1930s, Herbert Marcuse wrote about the "affirmative character of culture," that the artwork shows an image of a different world but simultaneously confirms this world and, thus, functions as a 'safety valve'; in the late 1960s, Mario Perniola described art as the only permitted form of creativity in capitalist society, a limited and separate form of creativity and freedom without practical consequences.

Rasmussen then accuses me of ignoring or denying the implicitly compromised or complicit nature of art (the second half of its "dual nature").

Kester seems uninterested in this duality, which has to do with art's institutional status. It is almost as if Kester believes that by physically moving outside the traditional spaces of art, socially engaged art also escapes the conceptual space of its institutions or, at least, that there is some kind of qualitative transformation taking place for which the critical field analysis must account.

I would begin by noting that I have never stated that SEA projects somehow elude compromise or complicity simply by virtue of being staged outside of conventional art spaces. In fact, I have devoted a considerable amount of time in my past research to addressing precisely these forms of complicity. ${ }^{7}$ I simply argue that the compromises involved in SEA are often of a different order, depending on the institutional and discursive frame within which the work operates. What I would want to challenge here, though, is the underlying assumption that any practice can remain entirely pure and politically uncorrupted, and that the failure to do so effectively destroys its transformative potential in its entirety. I think there is a 
rigidity in this expectation that can blind us to the actual nature of political change, and the possibility of new forms of creative resistance that may challenge our a priori assumptions.

Some further clarification may also be in order. It is helpful to recall that Marcuse, in his critique of the "affirmative" quality of art (that is, its tendency to offer an escape from capitalist repression rather than challenging it directly) was talking specifically about art practices that set themselves entirely apart from "the everyday world" to become an object of "spiritual contemplation." The situation is somewhat different with SEA projects that seek to challenge this mode of absolute autonomy by engaging directly with forms of social or political resistance (involving what I would term a situational model of autonomy). Further, Rasmussen's analysis of art as a utopian "safety valve" misses the key shift that takes place between original models of aesthetic experience based on a redemptive (and contemplative) notion of beauty, and the avant-garde traditions of the early twentieth century, that will challenge the idea of beauty as yet another instance of the "premature" claim that the freedom promised by aesthetic experience has been universalized. ${ }^{8}$ In response, avant-garde discourse will simply invert the paradigm of beauty as a prefigurative experience of the reconciliation of self and other, and instead devote itself to strategies intended to prevent this premature reconciliation, by punishing, assaulting or disrupting the viewer to remind them of their class specificity, rather than offering them a spurious class transcendence (what Adorno terms art's "admixture of poison" in Aesthetic Theory). ${ }^{9}$ Here the insurrectional energies of the working class and the violence of an always-deferred revolution are projected into the oppositional schema of the avant-garde artwork in its relationship to a hypothetical (always bourgeois) viewer. This discourse also provides the template for Rasmussen's concept of an art of "unreasonable demands" and, not coincidentally, for the valorization of an arrested form of negation as the primary modality of critical and creative intelligence which, as we will see below, is central to Rasmussen's identity as a critic and theorist.

Given these historical shifts I believe the more precise way to frame this critique would take the following form:

- SEA can be co-opted by the capitalist system by convincing us that real change can be produced by "modest gestures" of situational or local social change. 
- The "state" (variously the "bourgeois," "capitalist," or "liberal democratic state") can point to these modest changes as evidence that it is capable of changing, and validate its refusal to engage in a more systematic transformation.

- The result is to further repress, derail or defuse an authentic revolutionary ethos which might otherwise be more likely to emerge.

This is, of course, a relatively familiar criticism. I address it in the "Theory and Practice" essay, referenced above, where I define it as an "exculpatory critique". As noted above, I am entirely sympathetic with this set of concerns. However, as I have also observed, this critique is necessary but not sufficient. It can, if elaborated within an excessively mechanistic model of political change, become constraining and even conservative. In the "Theory and Practice" essay I describe this tendency in terms of a problematic devaluing of practice. Thus, the exculpatory critique can be used to argue that:

any form of art practice that produces some concrete change in the world or is developed in alliance with specific social movements (via the creation or preservation of a park, the generation of new, prefigurative collective forms, shifts in the disposition of power in a given community etc.) is entirely pragmatic and has no critical or conceptually creative capacity. Or, alternately, that such projects, by suggesting that some meaningful change is possible within existing social and political structures, do nothing more than forestall the necessary, but inevitably deferred, revolution.

What we lose sight of here is the generative nature of resistance itself, at the local or situational level. While Rasmussen makes frequent references in his FIELD essay to "real change" it is not entirely clear what he means by this. We can gain a better sense of what he might have in mind if we turn to his 2014 essay "Here and Elsewhere," where he is insistent that we must continue to identify the "communist project" and "communist revolution" as the only possible framework for revolutionary change. ${ }^{10}$ We might then wonder how Rasmussen comes to terms with the almost total absence of "communism" as a frame of reference for social movements over the past few decades (outside of a small number of cases, such as the Naxalites in central India, Nepalese Maoism, Shining Path in Peru, etc.). In his account the loss of the redemptive horizon 
promised by communism is a result of the deliberate repression of communist discourse by bourgeois capitalism, which has actively attacked it and circumvented its spread. There is, revealingly enough, no reference in his description to the ways in which actually existing communism, in its performance as social and political system, might have resulted in certain tendencies (the repression of dissent, dynastic regimes, one-party rule, Nomenklatura-based social and economic hierarchies, etc.) that have contributed to its de-legitimation among a more recent generation of activists. These can all be ascribed, conveniently enough, to the simple fact that those regimes that we typically identify as "communist" or "socialist" were, in fact, simply not communist enough, and therefore allowed incipient capitalist tendencies to deform their immanent, utopian nature.

This leads to the one-dimensional form taken by Rasmussen's historical summary: "the Soviet Union was never socialist," Mao Zedong and Ho Chi Minh's economic policies were "... variants of state capitalism," and the entire Pink Tide period in Latin America amounted to nothing more than "state capitalist reforms." With "communism" safely reinvented as a purely metaphysical concept (Rasmussen refers to the "elimination of the state" and "money" that will accompany a true communist revolution, with no explanation of how a social system responsible for meeting the material needs to millions, or billions, of individuals would function in the absence of an institutional structure that does not posses some state-like qualities). ${ }^{11}$ While we are entitled to critique "actually existing capitalism" on the basis of its failures, actually existing communism, as such, does not really exist in Rasmussen's account. As a result he is under no obligation to ask himself why Islamic fundamentalists and populist neo-fascists can recruit with alarming ease among the poor and working class, while the glorious cause of a fourth International languishes in obscurity. In particular, he seems incapable of realizing that there may be something in the way in which the communist and socialist left itself has communicated its vision, and made it relevant (or not) to people's struggles and lived experience that has retarded its progress. The only possible point of revolutionary hope that Rasmussen seems willing to recognize is the Arab Spring which he presents, somewhat improbably, as a well-spring of proto-proletarian revolutionary fervor, even as many of the protestors at Tahrir Square, to use one example, were primarily concerned with decidedly liberal concerns such as governmental corruption, police brutality, free speech and democracy. 
It is not that Rasmussen's judgments do not contain a degree of truth (the capitalist attack on communism is a matter of historical record, many Arab Spring protestors were critical of neo-liberalism, and the failings of Chavez et.al. were fairly evident to most observers). Rather, it is his apparent reluctance to see anything of value in the partial forms of revolutionary change that have been achieved, whether under communism, socialism or even liberalism, and to view social change as a kind of zero sum equation which only matters if it emerges from a space that is entirely free and autonomous from existing political institutions and discourses. One wonders if it is possible that some small aspect of any of these past movements (the Bolshevik revolution, the Communist revolutions in China or Cuba, and even the more recent emergence of anti-globalization and "horizontalist" movements in Latin America or Spain) might shed some light on our current situation or provide some guidance or inspiration? On the one hand we have, in Rasmussen's account, a system of capitalist repression so seamless, so pervasive and so monolithic that it can appropriate even the most minor gesture of resistance or change, and on the other the insistence that any challenge to this system must emerge from a political space that is entirely separate from it; that can in no possible way be seen to bear the marks of democracy, the state, rights, or any number of other concepts that are now to be understood as irrevocably contaminated by their affiliation with the capitalist juggernaut.

So, what would "real change" look like for Rasmussen? This is not entirely clear in his writings, but if he is to remain consistent with the traditions of Communist political theory it would entail some sort of cataclysmic revolutionary overturning which completely transforms the existing (capitalist) social and economic order, along with our underlying human nature, which has been fundamentally altered by bourgeois modes of possessive individualism. In this case, anything short of an absolute destruction of the existing order can be dismissed as reformist, complicit or counter-revolutionary. Here "revolution" is defined as a form of political autopoiesis, inventing itself in its entirety ex nihilo, and rendering all existing institutions and political discourses obsolete in the process. There is a venerable tradition behind this model, but it is not without its limitations. For my part, I believe that political change always emerges out of a pre-existing set of material, discursive, institutional and counter-institutional practices. This temporal continuum is paralleled by a spatial continuum, through a mode of capillary action that runs from individual consciousness to collective action and violent resistance, and that involves 
the emergence of new solidarities, and their subsequent dissolution, moments of provisional consensus, and moments of dissensus. What we call the "Russian Revolution” didn't begin with Lenin, it began with the resistance movements of the nineteenth century, with the Kolokol, with the Peasant Movement, with Zemlya I Volya, with Young Russia, which led eventually to the February revolution which actually deposed the Tsar, which led finally, to the Bolshevik takeover (which was less a taking-over than a picking-up, as Hannah Arendt famously observed). Each of these nodal points was decisive in producing the eventual transformation that we describe as the Russian Revolution.

I would argue that in writing about SEA we need a more sophisticated model of political change, which can account for this capillary nature. Any work of art, even the most precious and privatized example of art for art's sake, has an "impact" in the transformation of an individual viewer's consciousness (or the accumulation of investment value). The challenge is determining how the transformation of consciousness through the encounter with a work of art might effect the viewer's subsequent actions in the world. This is the more interesting question: how do we determine what "change" means, what it looks like, and what forms of change are more creative, more generative or more transformative? Here is one provisional set of categories for understanding this question.

- Transformations in individual consciousness (which may, or may not, lead to a transformation in action or social agency, and which may or may not be serially communicated or transmitted to others). Evident in a myriad of art forms and practices.

- Prefigurative modeling (the creation, in various forms of activist practice, of new modes of social organization that challenge existing hierarchies of power, decision-making, creativity and so on). Evident in many contemporary art practices that involve the invention of new, para-institutional forms. In an essay in FIELD issue \#1 Francesca Polletta discusses the important points of conflict between this prefigurative dimension and the exigencies of direct action during the Civil Rights movement.

- Transformations in cultural or symbolic discourse (the introduction of new value systems, re-framing of debates or the alteration of social relationships at a given site). Evident in the work of Dialogue in Bastar, India, which I discuss in The One and the Many and the Transborder Immigrant Tool (discussed 


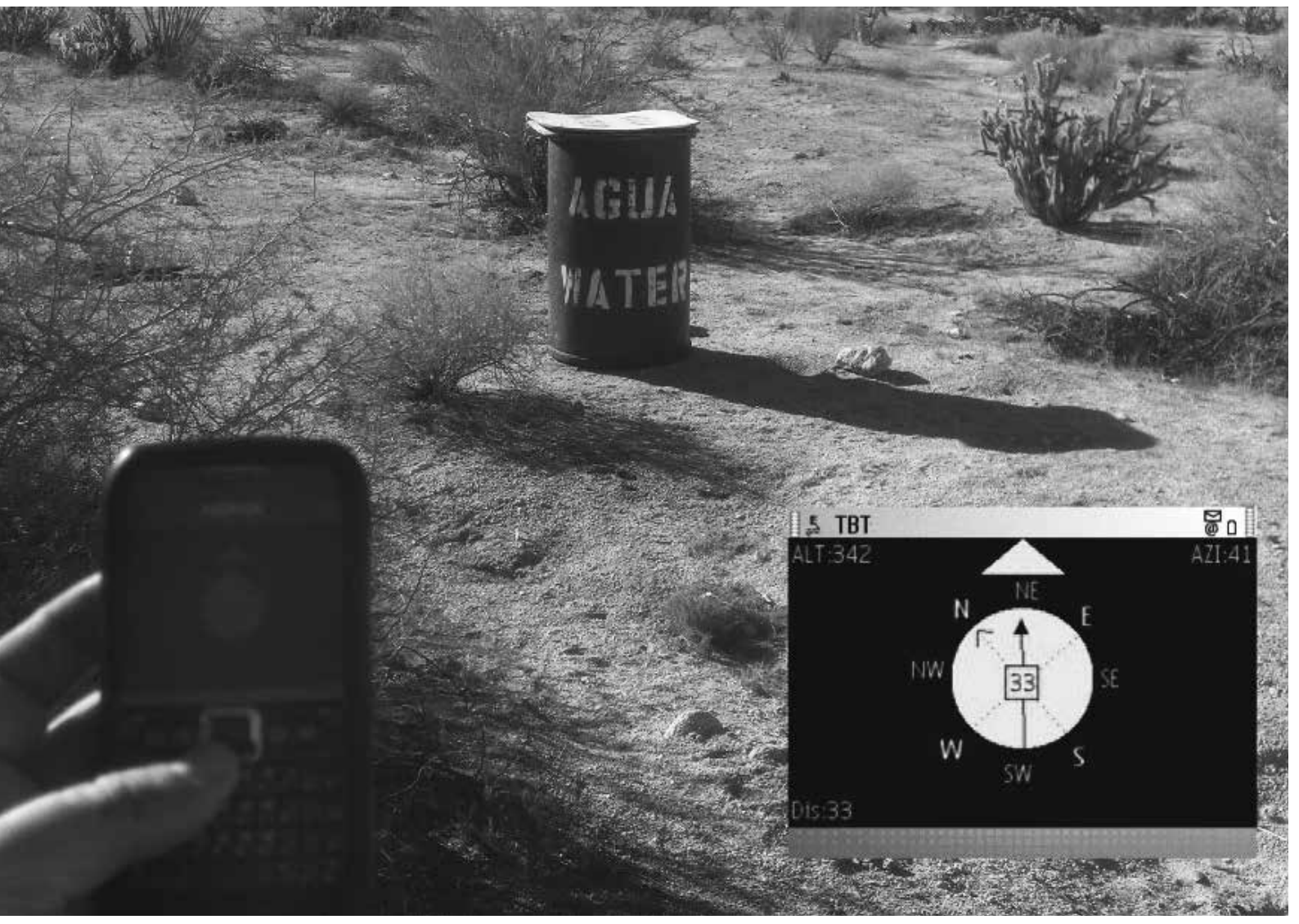

Electronic Disturbance Theater (EDT) 2.0/b.a.n.g. lab,

Transborder Immigrant Tool (2007-Present) 
in my essay "Waterworks: Politics, Public Art and the University Campus" in the Blackwell Companion to Public Art, 2016).

- The re-shaping of spatial boundaries, the defensive partitioning of space or territory, or the temporary occupation of public space. Evident in the anti-gentrification struggles of groups like Park Fiction, also discussed in The One and the Many. I would also consider the covert street performances of NICA in Rangoon, under the military junta, an example of a particularly localized manifestation of this impulse (necessarily so, since any anomalous public behavior could lead to arrest)

- The re-shaping of temporal frames, via the blocking or delaying of repressive action (evident most recently in the initial victory of the Water Protectors at Standing Rock, in South Dakota, strikes, recent forms of "slow activism," etc.).

- Transformations in public policy (governing the police, social policies, property, housing, corporate conduct, etc.) Evident in Wochenklausur's Boat Talks on Lake Zurich, which I discuss in Conversation Pieces, Teddy Cruz's work around urban zoning policies and recent activism associated with the Black Lives Matter movement.

- Transformations in political regimes, at the local, regional or national level (which might call on any number of specific strategies). Evident in the Lava la Bandera project discussed above, the January 25 Revolution in Egypt and elsewhere.

Taken in the aggregate these are some of the imperfect, messy, improvisational and inevitably compromised modalities by which political and social change actually occurs. They often coexist within a given activist project, and can operate on a continuum with open violence and insurrection. The extent to which any project is meaningfully transformative, creative or revolutionary (or has a potential to effect events beyond its local context) has to be gauged through a detailed, situational analysis of these interactions, among many others. They each involve encounters that can provoke new insights and new modes of practice and which can, in turn, provide the foundation for subsequent action and insight. In this sense they can be simultaneously pragmatic (involving processes of concrete problem solving), diagnostic (revealing new cognitive and institutional blockages and openings) and prefigurative (disclosing new modes 
of contestation that might be scalable or replicable in the future as well as new insights into the process of social change more generally). The question that Rasmussen raises, of course, is whether all of these registers of practice or resistance are simply reiterations of the same "modest" problematic, since none of them can be guaranteed to lead irrevocably to the total destruction of global capitalism and few of them openly espouse the cause of global communist revolution which he has identified as the single legitimate telos of real political change.

\section{ŽIŽEK AT THE FINLAND STATION}

This question leads us to what I believe is the most generative point in our exchange, which revolves around the role of the critic or theorist. We can begin this discussion with Rasmussen's response to my treatment of Adorno in the "Theory and Practice" essay. It is worth quickly reviewing this reference, since it was offered in passing to make a broader point. At its founding in 1931, the Frankfurt School ethos was defined by a commitment to trans-disciplinary research (across the fields of political economy, psychology, sociology and aesthetics) devoted to the critical analysis of capitalism (and nascent fascism). This research was to be developed in support of the broader mosaic of left-wing and working class political movements active in Germany at the time. At this stage, as we see in Horkheimer's inaugural address, the domain of "culture" (not simply art, but popular and mass culture) was understood as a field of quasi-autonomous "social action" with at least the potential to challenge the economic imperatives of capitalism. By the mid-1940s, and the publication of The Dialectic of Enlightenment, the Frankfurt School model of critical theory has changed dramatically, and taken on the more elegiac tone we are familiar with from art world presentations of Adorno. We have in this book an almost entirely monolithic account of the appropriative power of the capitalist system that is, moreover, projected back into the earliest stages of human history (through what Adorno and Horkheimer term "retrogressive anthropogenesis"). Three conclusions follow from this diagnosis:

1. Real or substantive political change is now impossible due to the consolidation of "state capitalism," which is the institutional form taken by instrumental reason.

2. Culture in general has become entirely coopted by a "totally administered society.” As a result, the only space within existing 
society where an authentic revolutionary impulse might be preserved is in certain very specific forms of avant-garde art and (aesthetic) theory. The sanctity of this revolutionary truth can be maintained only so long as avant-garde art and theory remain entirely disconnected from practical experience and action. Here the artist becomes a "deputy," as Adorno writes, on behalf of an ideologically subservient working class no longer able to realize its historical destiny. ${ }^{12}$

3. As a result there is no point in either engaging in forms of practical resistance, or of investigating the possible connection between art, theory and social change. First, because the social science methodologies necessary to conduct this research are, themselves, merely extensions of instrumental reason, and second, because any attempt to actualize the insights of theory in practice, or to establish a reciprocal interconnection between theory and practice will, inevitably, lead to the cooption and degradation of theory's revolutionary purity.

For Adorno it is precisely in the sequestered, "inward" consciousness of the theorist or artist that a pure form of revolutionary thought can be preserved. As a result theory, like art, must remain aloof and disengaged from questions of practice, application or positive action. Adorno treats both theory and practice as fixed constructs, and their reciprocal engagement (or lack thereof) as occurring in an oddly a-temporal field. The result is an absolutist model of theoretical and aesthetic autonomy that fails to account for the ways in which theory might bear a shifting relationship to practice over time, moving from a phase of immersive or direct engagement to a phase of contemplative reflection and back again (one should note here that Marcuse's critique of the "dual nature" of art can be applied with equal relevance to the discourse of theory). How, in fact, does one determine when the historical moment has arrived that might allow for the re-actualization of theoretical truth without some way of analyzing unfolding forms of political action? Theoretical truth, like aesthetic experience, is not meant to be tested by practical experience, nor does it evolve out of a dialogical relationship with practice. Instead, the telos of social or political transformation is already known by the theorist in advance and practice is reduced to the merely utilitarian application of an a priori theoretical "truth" necessary to produce this end. Thus, while Adorno challenged conventional notions of the aesthetic based on the transcendent experience of beauty he reproduced the 
underlying schema of aesthetic autonomy. This schema is predicated on a fixed boundary between the profane social world and the redemptive interiority of individual consciousness; the site at which all meaningful insight generation occurs (to be subsequently applied to practical, collective action in that world).

Given Adorno's experience of fascism and the rise of consumer capitalism in the post-WWII period his pessimism is entirely understandable. The question we face today is whether or not the absolute detachment of critical theory from practice (and of art itself from political and social change) that, for Adorno, followed naturally from his melancholic assessment of the political situation is still useful or empowering. In fact, it is around this question of theory, practice and the potential for social change that Adorno's falling out with Herbert Marcuse occurred in 1969 (as documented in their letter exchange re-published in FIELD Issue 5). In January of that year Adorno had called in the police to break up an occupation of the Frankfurt Institute offices by student protestors associated with the Außerparlamentarische Opposition or APO. Marcuse, learning of Adorno's actions, wrote him to express his disagreement, and his support of the student activists. Adorno, for his part, dismissed the protestors as opportunistic and politically naïve. The decisive exchange circulates around the relationship between theory and practice. Marcuse writes:

I would have left them [the protestors] sitting there and left it to somebody else to call the police. I still believe that our cause ... is better taken up by the rebellious students than by the police and, here in California, that is demonstrated to me almost daily... You know me well enough to know that I reject the unmediated translation of theory into praxis just as emphatically as you do. But I do believe that there are situations, moments, in which theory is pushed on further by praxis-situations and moments in which theory that is kept separate from praxis becomes untrue to itself.

Adorno's response is symptomatic:

You think that praxis ... is not blocked today; I think differently. I would have to deny everything that I think and know about the objective tendency if I wanted to believe that the student protest movement in Germany had even the tiniest prospect of effecting a social intervention ... I would ... concede to you that there are moments in which theory is pushed on further by practice. 
But such a situation neither exists objectively today, nor does the barren and brutal practicism that confronts us here have the slightest thing to do with theory anyhow. ${ }^{13}$

In an analysis that prefigures in many ways Rasmussen's critique of "modest gestures," Adorno attacked the APO activists on the basis of their reliance on "action-ism," or the naïve belief that "if only you change little things here and there, then perhaps everything will be better." "Action-ism can essentially be traced back to despair," as Adorno observes, "because people sense how little power they actually have to change society. But I am equally convinced that these individual actions are predestined to fail.”14

Rasmussen, like Adorno, views the avant-garde as a unique vessel of revolutionary truth. Thus he links the "disappearance of the avant-garde" in the past few decades directly to the "disappearance of a revolutionary perspective and the closing down of a radical horizon.” 15 He also believes that avant-garde tactics of shock or disruption constitute a kind of somatically displaced form of revolutionary assault, necessary to "wrest humanity free from the instrumental rationality of bourgeois society and supercede the alienating relations of capitalism." 16 But does Rasmussen also share Adorno's view of the impossibility of meaningful social change? Rather than address the more systemic questions raised in my essay around the nature of political change, Rasmussen instead reviews the litany of failures associated with the repression of communism during the twentieth century.

Kester does not deal with the historical development from the revolutionary take off in the years between 1917 to 1923: the preventive (Italian Fascism) and the 'finishing' (German Nazism) counter-revolutionary derailment of the revolutionary offensive in Western Europe, the state-capitalist counterrevolution in the Soviet Union, to the economic crisis and the anti-Fascist fight, World War Two and "the massacres of the slaves of capital," as Amadeo Bordiga calls it, as well as the reconstruction of the apparatus of production in Western Europe after the end of the war, which resulted in high profit rates and the narrowing of the political horizon within the framework of the Cold War.

I suspect that this historical summary is meant as a corrective to what Rasmussen imagines is my overly optimistic or naïve view of the possibilities of meaningful political change today. At the same time, it can easily enough be taken as verification of Adorno's 
pessimistic assessment that "no real change is possible." He then goes on to link my ostensible ignorance of this history with the transgressive goals of Adorno's critical theory.

But Kester's analysis moves quickly and disregards the substantive historical transformations taking place during these decades. This is a process in which the Western European working class movement inscribed itself in nation-state democracy, abandoning [the] last gasp of revolutionary demands for political rights and access to commodities and welfare. Critical Theory was actually trying to analyze this development (as were the Situationists and, later, Cultural Studies) in which working class identity and culture were gradually dissolved and replaced by new image-driven subjectivities devoid of political agency. To analyze this development as a question of abandoning empirical analysis is simply inadequate...

Adorno and Horkheimer still had an idea of an historical subject that had, no doubt, acquired a ghostly form in what Adorno describes as "the classless class society". But the task was to analyze that development. For Kester, this does not seem to be necessary; there is no such subject or even an idea of such a subject. There is just this world that socially engaged art can repair and ameliorate, which the socially engaged art critic can, then, describe.

Here Rasmussen collapses together a range of different intellectual traditions that have clearly incompatible perceptions of the efficacy of social and political change. Adorno, especially the later Adorno I reference in my essay, would have absolutely no patience for the kinds of reception studies and sociological research that were typical of the Birmingham School of Cultural Studies (e.g., Richard Hoggart's Uses of Literacy) not to mention Raymond William's redemptive concept of "culture" (Williams certainly would disagree that the working class was entirely "devoid of political agency"). Moreover, Adorno would have found the Situationists just as problematic as most other "new" art practices of the 1960s, which he dismisses in Aesthetic Theory as guilty of actionism and dedicated to the absolute destruction of art: "To call for the abolition of art in a society that is moving from partial to total barbarism is to invite co-optation by that society. The recent aesthetic activism keeps invoking concreteness but is woefully abstract and summary in its approach.”17 In 1964 Adorno even instituted legal 
proceedings against members of Subversive Aktion, a Situationistinspired group that had posted "wanted" posters featuring Adorno quotes around the University of Frankfurt campus. For their part, the Situationists would have no doubt considered Cultural Studies theorists, who imagined that they could observe the "resistant" consumption of mass culture by a working class enmeshed in the Society of the Spectacle, as hopelessly naïve in turn.

In fact, "Critical Theory," as I use the term in the essay that Rasmussen cites, was precisely not interested in analyzing the evolution of capitalism. That work had already been done (via Adorno's reliance on a functionalist merger of Frommian psychology and Friedrich Pollocks' analysis of "state capitalism" in the Dialectic of Enlightenment). Capitalism was, and remained, the straightforward extension of the relentless evolution of human consciousness towards total instrumentality. One could certainly spend a great deal of time pointing out the endless ways in which this instrumental reason continued to colonize the most intimate spaces of our public and private lives (even "casement windows," for Adorno are harbingers of capitalist oppression), but that's not the same thing as analyzing a "development" (which implies the possibility of change or historical movement that Adorno felt was foreclosed). ${ }^{18}$ That image, of a monolithic and implacable system of domination, and the impossibility of real resistance to it, is centered on a concept of fundamental stasis.

The crucial point that I raise in my essay "Theory and Practice" has nothing to do with my assessment of the relative efficacy of revolutionary struggle in the twentieth century. Rather, my intention was to challenge Adorno's assumption, disabling for us today, that the past failures of revolution mean that there is simply no longer any point in trying to learn about, and from, resistance today. And that "theory" or art must abjure any reciprocal relationship to practices of political resistance. And, finally, that the only space in which a "true" revolutionary knowledge can be maintained is the detached consciousness of the theorist or artist. Rasmussen is silent on these issues. Why does the historical fact of political failure necessarily lead us to believe that theory must be uncoupled entirely from practice? In Adorno's case the justification was clear; the existing system of domination was so implacable that revolutionary truth had to be hidden away, like a precious talisman, to be preserved for a future moment, when "objective" change was finally possible again. If all real change is impossible and if the theorist always/already knows in advance what real change looks like, there is no need to actually research social resistance here and 
now because the theorist has already grasped its utter futility. Does Rasmussen share this view? His often-schematic account of political history would suggest that he is sympathetic to it. At the very least it remains a significant point of tension in his analysis.

If we were to encapsulate the rhetorical essence of Rasmussen's position in his essay it might sound something like this: "If I am not vigilant, certain SEA projects that are, in fact, complicit with a repressive capitalist system might be given unearned political credibility. My primary job, as a theorist and critic, is to undermine the legitimacy of these projects, thereby robbing the capitalist system of the ideological validation that they provide.” The critic here plays a fundamentally prophylactic role, searching out hidden complicities, exposing unrecognized levels of compromise, and preventing the premature reconciliation of communism as metaphysical ideal and the inevitable reformism of practice. Rasmussen himself provides some support for this characterization in a recent interview in which he states:

I do not present any program to be realized anywhere. As a white, heterosexual, middle-class male it is not up to me to draw up any visions in the current historical situation. Rather, it is my task to help abolish all the models created by the Western enlightenment project: models that prevent others from being visionary. So yes, my project is negative in nature. It would be a great help to the processes that are now underway if we could effect a meltdown of all the passed-down notions about growth, market, national democracy, and state. That would almost be half a revolution in its own right. ${ }^{19}$

We have to first note the characteristically monolithic image of the "Western enlightenment project" in Rasmussen's response, which leaves us little hope for any possible improvement in our political condition short of a cataclysmic overturning of this entire edifice of domination. One also feels compelled to note the simple fact that "communism" itself is clearly a product of Enlightenment thinking, broadly understood (the influence of Comte and Rousseau on Russian political discourse is a commonplace), and bears those traces at many levels. Rasmussen envisions the audience for his gesture of pure negation to consist of those "others" whose task is "being visionary," but who are currently impeded in this task by their reliance on problematic political beliefs which he will dedicate himself to clarifying. He seeks to function here something like Žižek at Zucotti Park; the radical thinker edifying the social agents 


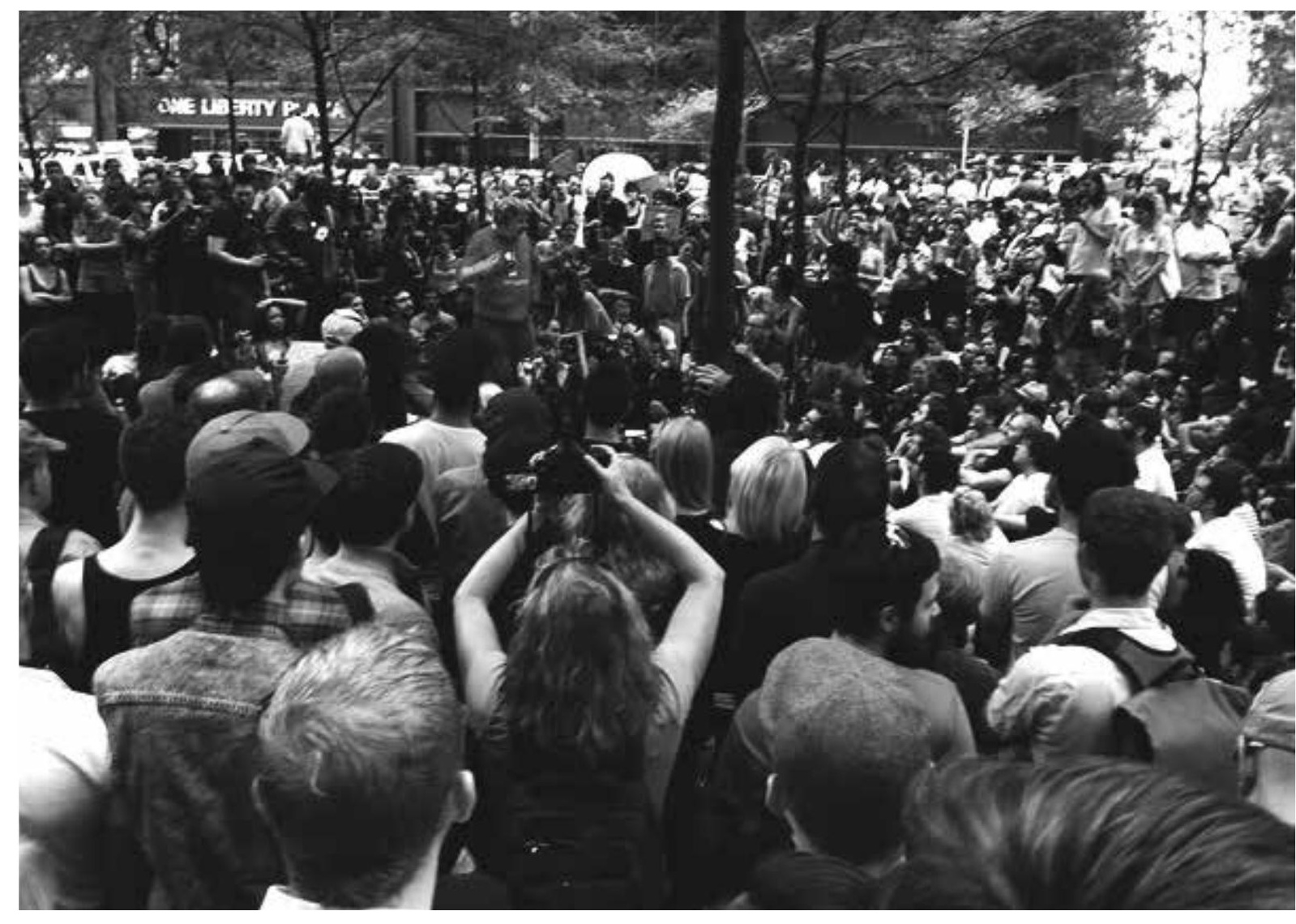

Slavoj Žižek at Zuccotti Park (October 9, 2011) 
charged with the physical and social labor of political transformation ("Don't fall in love with yourselves. We have a nice time here. But remember, carnivals come cheap.").

In the quote above Rasmussen appears to re-frame Adorno's theory/practice division as a division between the principle of pure negation (represented by himself as critic and theorist) and the "positive" moment of social change, which he will supervise not by dictating models but simply by determining which versions of social change are sufficiently revolutionary to meet his stringent criteria. The world of "visionary" action is defined as a field of potential error to be corrected, not lessons to be learned, and the theorist retains his sovereignty and his intellectual authority by restricting himself to the purely negative labor of critique produced in isolation from political praxis. I am not arguing that, as critics, we should surrender our skepticism or our willingness to situate specific practices in a larger political context, but I do think we have to consider the possibility that our own a priori assumptions about the nature of political change and revolution might need to be revised in the light of new, unfolding forms of resistance and activist practice today. And this requires, in turn, challenging to some degree the monological authority of theory and criticism itself. In this respect, the critic and theorist must also possess some visionary awareness; some capacity to see beyond the often simplistic binary oppositions between pure negation and positive action, between revolution and reform, between contemplative analysis and the act of resistance, and between theory and practice, that we can impose on the creative work of political change. It goes without saying that we should criticize those SEA projects that are complicit or depoliticized (there are certainly enough of them). But to present this state of complicity as the necessary and generic condition of any SEA project that produces concrete change, or that operates "modestly" in a local or situational context is, to me, to risk blindness to the very generative processes of resistance specific to our time, out of which new configurations of the political will, and must, evolve. Ultimately this is not an argument that can be won or lost logically; it is more a reflection of a Weltbild or style of thought. My hope in the redemptive potential of praxis to reveal new configurations of the political is no less utopian than Rasmussen's belief that the largely middle class protestors of Tahrir Square were the advance guard of an incipient "communist revolution". Having said that, I am very sympathetic to Rasmussen's frustration with the failure of the communist project, and his desire to hold the line against its further erosion by an act of intellectual will. These are certainly 
difficult times to live in for anyone who holds out hope for some form of social and political redemption and our only path forward requires precisely the kind of dialogue that Rasmussen has initiated here, as we think through the nature of resistance together. Rasmussen has raised a number of essential questions, and while I might disagree with aspects of his analysis, I share his concern with the many compromises imposed by capitalism on the human desire for a society based on freedom and equality, and value the opportunity that our exchange has provided to explore these questions more deeply. 
1 Alice Jardine and Brian Massumi, “Interview with Toni Negri," Copyright \#1 (1988): 74-75.

2 I will address one other minor point in this note. I believe I understand what Rasmussen means by the "formal" aspects of a work, but I may also be misunderstanding him. If by "formal" he is referring to the compositional manipulation of a set of abstract visual or physical properties within a closed, purely self-referential system, then I would probably agree with him. However, I would also argue that there is a highly complex formal or "architectonic" (to use Bakhtin's term) system at work in many of the SEA projects I have discussed in my own research. It is structured through somatic, social, physical and verbal interaction that is inter-subjective and also directed at specific institutional and discursive structures, associated with processes of resistance. I do not believe I have ever stated that the critic's job is to simply "report with empathy." Here I think Rasmussen may be confusing the role of empathy as it is negotiated within a particular work, and the critic's relationship to a given project. While I do think that part of the evaluative process of certain forms of SEA requires an analysis of the various modes of intersubjective exchange that unfold in a given work, I would be cautious about reducing the role of the critic to simply experiencing "empathy," and this seems at odds with my own approach.

3 See Gustavo Buntinx, "Lava la bandera: el Colectivo Sociedad Civil y el derrocamiento cultural de la dictadura en el Perú," E-misférica journal 3.1 (June 2006) http://hemisphericinstitute.org/journal/3.1/eng/ en31_pg_buntinx.html

4 For more information on the Escraches see: http:// www.hijos-capital.org.ar/index.php?option $=$ com $_{-}$ content\&view=section\&layout=blog\&id $=7 \&$ Itemid $=407$

5 Here I will list Rasmussen's original passage, followed by my response.

"The critic is supposed to go where the projects go, observing them as they unfold over time. Kester writes that the critic must "empirically" "verify" the artistic projects and their "results" although how that is to take place remains unclear. Instead of continuing the critical analysis of the anthropological turn of politicized contemporary art, Kester proposes to expand it and apply it to art criticism, without mentioning the widespread critique of the ethnographic practice of field study that has taken place over the last thirty years... And this does not even mention the imperialist prehistory of ethnography that has always haunted anthropology and forced it to challenge the idea of an outside, scientific researcher who uses neutral language to analyze the 'raw' material gathered..."

I am not unfamiliar with critiques of anthropology or ethnography. If I were invoking ethnography as it was practiced two or three decades ago as a model I might find this critique more compelling. In fact, contemporary anthropology presents a range of useful paradigms, from the tradition of collaborative ethnography involving a process of "co-theorization" with social movements (especially well developed in Colombia) to George Marcus's "multi-sited" ethnography (Marcus is also a FIELD editorial board member whose work we have published), to recent projects by Shannon Speed working in Chiapas, or Alex Flynn's work with the Landless Workers Movement in Latin America, among many others. None of these approaches treat the site of research from the perspective of naïve empiricism and all are fully cognizant of the problematic colonialist histories of the discipline that Rasmussen seems to imagine as a kind of scandalous secret. What interests me about this criticism is less its cogency than its symptomatic nature. Art theorists frequently employ ideas drawn from an array of other disciplines without feeling compelled to repeatedly "reveal" the surprising truth that these disciplines have problematic histories or that they have evolved over time. The skeptical response some art critics have to the disciplines of ethnography or anthropology seems to be tied to an almost instinctual resistance to direct, observational or participatory engagement with practice.

One wonders what possible threat might it pose to our own theoretical equanimity to speak directly with the participants, collaborators or other social actors involved in the creation of a given work or to analyze the process of cultural or political resistance or creativity that unfolds at a specific site? Adorno, of course, was highly critical of any attempt to develop an analytic account of the actual reception of music (he singled out German sociologist Alphonse Silbermann in particular for attack), which would have the effect of confirming, or challenging, his own often hyperbolic theories about how people react to specific musical forms. This was because, first, he viewed all forms of social science as little more than the handmaidens of instrumental reason (notwithstanding his own reliance on sociological research in The Authoritarian Personality) and second, because he felt that art, and his own description of how art might transform the viewer's consciousness, was never really intended to describe the experience of actual viewers, but was intended instead to evoke an ideal or hypothetical viewer yet-to-be. There were many reasons for this belief, but suffice it to say that I find this to be an unsatisfying theoretical framework for the analysis of SEA projects that do not treat the viewer or collaborator as a surrogate for a generic bourgeoisie subject. Having said that, FIELD has clearly not yet done enough to elaborate more fully on the points of productive overlap between anthropological and art historical research, and we plan to focus on this question more fully in future issues.

- "Social movements do not figure in Kester's discussion of the socially engaged art critic: there is no Occupy, no Black Lives Movement". A detailed response to this question would require some discussion of what we each mean by the term "social movemen.t" I offer the examples below simply by way of clarification. In the course of its first five issues FIELD published two lengthy essays on Occupy Wall Street (OWS), an essay by Christoph Schäffer that addresses the occupation of Gezi Park in Istanbul, an essay by sociologist Francesca Polletta that examines the relationship between race and participatory democracy in the U.S. Civil Rights movement, and a letter exchange between T.W. Adorno and Herbert Marcuse discussing their respective 
perceptions of the student movements of the 1960s in Germany and the U.S. We have essays forthcoming on the role of the Sem Terra movement in Brazil, and an overview of Latin American activist art that relates this practice to social movements in the global south. We are also in the early planning stages for a special issue on race and incarceration. OWS and Black Lives Movement (BLM), of course, didn't exist when I was writing Conversation Pieces (University of California Press, 2004) and The One and the Many (Duke University Press, 2011). However, in both books I do discuss a range of other social movements, including the labor movement in the US/Mexico border region, protests against police violence in Oakland, California, the anti-gentrification movement in Hamburg, Germany, etc.

6 This criticism mirrors an analysis developed by the BAVO Collective almost ten years ago in "Always Choose the Worst Option: Artistic Resistance and the Strategy of Over-Identification," BAVO Collective (June 26, 2008), 24, 20. Available at: http://www.bavo.biz/texts/view/45. BAVO consists of Gideon Boie and Matthias Pauwels, working out of Rotterdam and Brussels. I respond to this criticism in The One and the Many, 223-226.

7 In both Conversation Pieces and The One and the Many l examine the ways in which SEA projects can be appropriated by various state and private entities in some detail (in my discussions of Dawn Dedeaux's Soul Shadows, Suzanne Lacy's The Roof is on Fire, Rick Lowe's Project Row Houses and Park Fiction, among several other examples). FIELD has also focused on this question. We have published a two-part critical essay on the discourse of participatory design by C. Greig Crysler as well as an essay by Caroline Lee, a leading sociologist who researches the ways in which concepts of political "participation" have been bureaucratized in the U.S.

8 In this respect, Marcuse's treatment of the avant-garde as a component of "controlled desublimation" in One Dimensional Man (written almost thirty years after the "Affirmative Character of Culture") might be a more useful frame of reference for current debates.

9 Theodor Adorno, Aesthetic Theory, edited by Gretel Adorno and Rolf Tiedemann, translated by C. Lenhardt (London: Routledge, 1984), 193.

10 See "Here and Elsewhere" on Open! Platform for Art, Culture and the Public Domain (September 4, 2014). https://www.onlineopen.org/here-and-elsewhere, p.1. In this essay Rasmussen identifies Occupy Wall Street as "the first nationwide protest movement in the U.S. since the late 1960s." This claim, however, ignores a number of significant precedents. One would certainly want to include on this list the anti-nuclear movement, which generated national support throughout the 1970s and ' 80 s, nation-wide protests during the Reagan administration against U.S. involvement in Central America, protests and demonstrations attacking U.S. policies on AIDS and HIV during the late 1980s and 1990s, Jesse Jackson's National Rainbow Coalition, which had branches throughout the U.S. during the 1980s and early 1990s, the Million Man March initiated by Louis Farrakhan in the mid-1990s, and ongoing mobilization by the feminist and environmentalist movements during the past four decades.
11 Ibid., 5. One is reminded here of Friedrich Engels' sarcastic summation of Bakunin's anarchism: "authority = state = absolute evil." "In this society [the Bakuninist ideal future society] there will above all be no authority, for authority $=$ state $=$ absolute evil. (How these people propose to run a factory, operate a railway or steer a ship without a will that decides in the last resort, without a single management, they of course do not tell us). The authority of the majority over the minority also ceases. Every individual and every community is autonomous; but as to how a society of even only two people is possible unless each gives up some of his autonomy, Bakunin again maintains silence." Friedrich Engels letter to Theodor Cuno (January 24, 1872), https://www.marxists.org/archive/marx/works/1872/ letters/72_01_24.htm.

12 Theodor Adorno, "The Artist as Deputy," Notes to Literature, volume one, translated by Shierry Weber Nicholsen (New York: Columbia University Press, 1991), 67.

13 The translated version of Adorno and Marcuse's letters first appeared in New Left Review I/233 (JanuaryFebruary 1999): 123-136. The quotes above are from pp.125, 127.

14 Gerhard Richter, "Who's Afraid of the Ivory Tower? A Conversation with Theodor W. Adorno," Monatshefte, vol. 94, no. 1 (Spring 2002): 17.

15 Mikkel Bolt Rasmussen, "The Self-Destruction of the Avant Garde," in The Idea of the Avant Garde and What it Means Today, edited by Marc James Léger (Manchester: Manchester University Press, 2014), 123.

16 Ibid., 121.

17 Aesthetic Theory, 356.

18 "What does it mean for the subject that there are no more casement windows to open, but only sliding frames to shove, no gentle latches but turntable handles, no forecourt, no doorstep before the street, no wall around the garden? [...] The movements machines demand of their users already have the violent, hard-hitting, unresting jerkiness of Fascist maltreatment." Theodor Adorno, Minima Moralia: Reflections from Damaged Life, translated by E.F.N. Jephcott (London: Verso, 1984), 40.

19 Jacob Lillemose, "An Art Historian with a Cause," Kunstkritikk (December 18, 2013), http://www. kunstkritikk.com/artikler/an-art-historian-with-a-cause/. 